\title{
FENOMENA DALAM BERITA COVID-19
}

\author{
Shella Anggarini \\ Universitas Diponegoro \\ anggarinishella@gmail.com
}

\begin{abstract}
Abstrak
Tujuan dari penelitian ini mendeskripsikan cara individu melakukan pemrosesan informasi dan menemukan makna kehadiran fenomena Covid-19. Penelitian ini menggunakan dua tradisi, yaitu tradisi sibernetika dan fenomenologi. Perspektif Elaboration Likelihood Theory, menjelaskan berbagai cara individu dalam mengevaluasi sejumlah informasi tentang Covid-19 yang diakses individu. Metode yang digunakan adalah fenomenologi dengan melakukan pengumpulan data melalui indepth interview terhadap empat orang informan. Hasilnya memperlihatkan bahwa para individu selalu terhubung dengan sejumlah media massa seperti radio, koran, majalah, televisi, media luar ruang (baliho dan billboard), serta internet untuk mengakses beragam informasi sehari-hari. M edia internet cenderung menjadi media yang dominan dipilih dan digunakan, karena lebih bersifat universal-archive, sehingga informasinya dapat diakses sewaktuwaktu. Berita atau informasi tentang Covid-19 diperoleh dari berbagai saluran informasi yang digunakan oleh masing-masing individu. Para informan memberikan penilaian secara beragam mengenai fenomena Covid-19, berita Covid-19, dan upaya pemerintah dalam mengatasi pandemi Covid-19.
\end{abstract}

Kata Kunci : Covid-19, Elaboration Likelihood Theory, Fenomenologi, Sibernetika, Virus

\begin{abstract}
The purpose of this qualitative research is to describe how individuals process information on the Covid-19 virus and find the meaning of the presence of the Covid-19 phenomenon. This research uses two traditions, namely cybernetics and phenomenology. The Elaboration Likelihood Theory perspective, explains the various ways individuals evaluate a number of Covid-19 virus information accessed by individuals. The method used is phenomenology with data collection with indepth interview instruments from four informants. The results of this study show that individuals are always connected to a number of mass media such as radio, newspapers, magazines, television, outdoor media (billboards), and the internet to access a variety of daily information. Internet media tends to be the dominant media chosen and used, because it is more universal-archive, so that information can be accessed at any time. News or information about the Covid19 is obtained from various information channels used by each individual. Informants provide a diverse assessment of the Covid-19 phenomenon, news of the Covid-19, and government efforts to overcome the Covid-19 pandemic.
\end{abstract}


Kata Kunci : Covid-19, Cybernetics, Elaboration Likelihood Theory, Phenomenology, Virus

\section{Pendahuluan}

Berita mengenai Covid-19 atau virus corona, cenderung memunculkan cognitive dissonance dan perubahan afektif dalam diri individu yang mengakses informasi teraktual sehari-hari dari berbagai media massa. Adanya sejumlah kasus yang berkaitan dengan kemunculan virus baru (SARS, M ers, flu burung, dan lain-lain), yang juga dapat menginfeksi manusia serta diberitakan secara meluas melalui media pada periode waktu sebelumnya, telah membentuk pengetahuan baru bagi khalayak yang mengkonsumsi informasi atau beritanya. Oleh karena itu, kemunculan berita tentang Covid-19 di media yang dapat diakses publik, mendorong berbagai reaksi dan tanggapan yang bervariasi dari masyarakat.

Mowen dan Minor (2002 : 375) menuturkan bahwa cognitive dissonance atau ketidaksesuaian kognitif merupakan keadaan emosional yang tidak menyenangkan. Keadaan ini dirasakan individu saat terdapat ketidakkonsistenan logis dalam unsur-unsur kognitif. Sebagian individu memberikan penilaian terhadap cara penyajian berita Covid-19.

Seorang pengguna instagram yang bernama @dr.tirta secara terbuka menyampaikan kritiknya kepada seorang reporter TVOne yang menggunakan masker gas, yang biasanya digunakan untuk menangkal gas dan logam berat, dalam menyiarkan berita tentang Covid-19 di Depok Jawa Barat. Menurutnya penampilan reporter tersebut terlalu berlebihan dan dapat menimbulkan kecemasan bagi para pemirsa televisi (grid.id, 2020). 


\section{Gambar 1.1}

\section{Potongan Gambar Tayangan Berita Covid-19 Di Televisi}

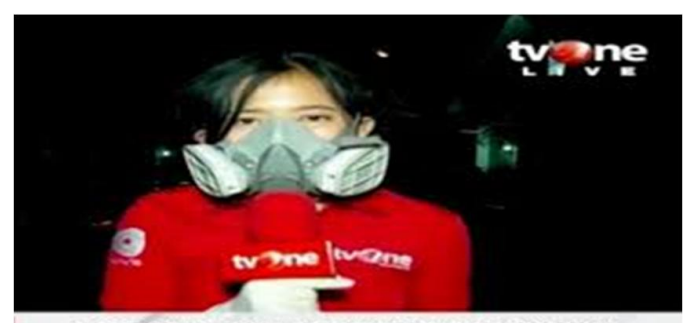

CORONA PUN MELANDA INDONESIA

Sumber : grid.id, 2020

Seorang pegawai hotel di Jakarta, Riski Wahyudi, menyatakan dirinya tidak terlalu khawatir dengan penyebaran virus Covid-19 yang telah memasuki Indonesia dengan menginfeksi dua warga Depok Jawa Barat. Menurut Riski, aspek terpenting agar dapat terhindar dari Covid-19 adalah tetap menjaga kesehatan diri. Pada sisi yang lain, penilaian berbeda diberikan oleh Azizah Rafa Karina, seorang siswi Sekolah M enengah Atas (SM A) Al Azhar. Sebagai seorang pelajar, dirinya tetap waspada terhadap virus ini. Azizah mencari berbagai informasi tambahan melalui media internet sebagai upayanya mengedukasi diri dan antisipasi terhadap hoaks Covid-19. Selain itu, ia juga aktif mengikuti sosialisasi yang diadakan di sekolahnya (news.act.id, 2020).

Adanya pengaruh eksposur media mengenai pemberitaan kasus Covid-19 dan perkembangannya, menimbulkan kebutuhan lain yang tidak diharapkan dari konsumsi media. Hal ini terlihat dari munculnya perasaan tidak nyaman, keresahan, dan lain-lain yang dirasakan oleh sejumlah masyarakat yang terpapar pemberitaan media. Seperti yang terjadi di Natuna pada sekitar bulan Februari 2020, sejumlah warga menolak wilayahnya dijadikan tempat karantina bagi para Warga Negara Indonesia (WNI) yang dievakuasi dari Wuhan Tiongkok oleh pemerintah pusat. Mereka khawatir tertular virus Covid-19 yang dibawa oleh para WNI. Selain itu, mereka beranggapan bahwa fasilitas kesehatan di Natuna tidak secanggih di Jakarta, sehingga memunculkan penolakan massal (liputan6.com, 2020). 
Seorang warga Yogyakarta, Nurkholis, memantau perkembangan kasus Covid-19 melalui televisi, terutama pada saat evakuasi kru WNI "Diamond Princess" yang diberitakan oleh media selama beberapa minggu. Menurutnya, pemberitaan media menjadi diantara dua sisi yaitu memberikan edukasi atau menciptakan ketakutan bagi masyarakat. Pemandangan seorang jurnalis yang menggunakan masker respirator dan memberitakan di sekitar lokasi terjadinya kasus Covid-19, dinilainya sebagai tindakan berlebihan yang dapat membuat dirinya merasa ngeri ketika menyaksikan berita di televisi (voaindonesia.com, 2020). Kecemasan sosial ini juga dilatarbelakangi pada pengalaman masa lalu, dimana banyak terjadi kasus-kasus penyakit yang disebabkan oleh virus seperti SARS, MERS, flu burung, dan lain-lain. Dalam perspektif ilmu komunikasi, kecemasan sosial berkaitan dengan kecemasan komunikatif-yang dideskripsikan dengan rasa takut atau khawatir, karena berada dalam situasi tertentu (DeVito, $2001: 80$ ).

Berbagai reaksi dan respon afektif bermunculan. Respon afektif adalah gambaran atau ekspresi perasaan dan emosi dari adanya stimulus (Engel, 1995 : 32). Disonansi individu atas sejumlah informasi yang diakses, membentuk gangguan kognisi. Kondisi inilah yang mendorong individu untuk mengekspresikan perasaan.

Covid-19 adalah virus yang menimbulkan gejala seperti batuk, demam, gangguan tenggorokan, atau hidung berlendir. Namun demikian, pada kasus tertentu, gejala ini dapat berubah menjadi penyakit serius (radang paru-paru atau pneumonia). Angka 19 pada nama Covid-19 dimaksudkan untuk memberikan keterangan bahwa virus ini tipe baru dari virus corona, karena jenis lain sudah ada sebelumnya (ayobandung.com, 2020).

Pada perkembangannya, virus ini menyebar ke sejumlah Negara lain secara global dan cepat. World Health Organization (WHO) mencatat, hingga tanggal 27 Maret 2020, Italia menjadi Negara dengan jumlah kematian tertinggi bagi para warga yang terinfeksi Covid-19. Secara keseluruhan, terdapat 465.915 
kasus dengan 21.031 orang meninggal di 199 kawasan dan Negara dunia. Tiongkok mencatat kasus tertinggi yaitu sebanyak 81.961 orang, dengan korban meninggal sebanyak 3.293 orang. Italia mencatat 74.386 kasus dengan jumlah korban meninggal mencapai 7.505 orang. Amerika Serikat mencatat 63.570 kasus dengan korban meninggal sebanyak 844 orang. Terdapat 47.610 kasus dan sebanyak 3.434 orang pasien meninggal di Spanyol. Jerman mencatat terjadinya 36.508 kasus dengan 198 kematian. Sementara Iran melaporkan adanya 29.406 kasus dengan jumlah kematian mencapai 2.234 orang. Perancis merilis adanya 24.920 kasus dengan korban meninggal sebanyak 1.331 orang (cnnindonesia.com, 2020).

Pada kasus di Indonesia, kasus warga yang terinfeksi positif Covid-19 telah mencapai 10.843 jiwa dengan korban meninggal mencapai 800 jiwa (kompas.com, 2020).

\section{Gambar 1.2}

Tabel Penyebaran Virus Covid-19 Di Indonesia

\begin{tabular}{|c|c|c|c|c|}
\hline - & DKI Jakarta & Terkonfirmasi: $\mathbf{4 3 9 7}$ & Meninggal: 392 & Sembuh: 513 \\
\hline - & Jawa Barat & Terkonfirmasi: $\mathbf{1 0 4 3}$ & Meninggal: $\mathbf{8 4}$ & Sembuh: 147 \\
\hline - & Jawa Timur & Terkonfirmasi: 1037 & Meninggal: 106 & Sembuh: 165 \\
\hline - & Jawa Tengah & Terkonfirmasi: 767 & Meninggal: 62 & Sembuh: 112 \\
\hline - & Sulawesi Selatan & Terkonfirmasi: 577 & Meninggal: $\mathbf{4 0}$ & Sembuh: $\mathbf{1 4 5}$ \\
\hline - & Banten & Terkonfirmasi: $\mathbf{4 2 7}$ & Meninggal: $\mathbf{4 1}$ & Sembuh: 34 \\
\hline - & Nusa Tenggara Barat & Terkonfirmasi: $\mathbf{2 5 0}$ & Meninggal: 4 & Sembuh: 32 \\
\hline & Papua & Terkonfirmasi: $\mathbf{2 4 0}$ & Meninggal: 6 & Sembuh: $\mathbf{4 8}$ \\
\hline & Bali & Terkonfirmasi: 237 & Meninggal: 4 & Sembuh: 129 \\
\hline
\end{tabular}

Sumber : kompas.com, 2020

Siaran berita sering sulit dipahami oleh khalayak, karena terlalu banyak mengandung cerita. Pada konten visual dan verbal terdapat ketidakseimbangan. Khalayak diberi terlalu banyak gambar yang menyerang mental, namun konteks informasinya terlalu sedikit. Terkadang gambar yang digunakan juga tidak 
relevan dengan kisahnya-membingungkan dan tidak memberikan informasi (Baran dan Davis, 2010 : 316).

Pada konteks khalayak media, Nielsen menyampaikan hasil survei tentang penggunaan media massa oleh khalayak di Indonesia. Hasil survei ini memperlihatkan bahwa penetrasi penggunaan televisi sebagai medium seharihari khalayak masih yang tertinggi yaitu mencapai 96 persen. Sementara media luar ruang (53 persen) dan internet (44 persen) meraih posisi kedua dan ketiga. Posisi selanjutnya ditempati oleh radio (37 persen), koran (7 persen), serta tabloid dan majalah (3 persen) (databoks.katadata.co.id, 2020).

Informasi atau pemberitaan yang berkaitan dengan perkembangan Covid19 di Indonesia, cenderung mudah ditemukan. Berbagai informasi yang dikonsumsi individu khalayak, akan diproses dalam sistem kognitif, sehingga menghasilkan pengalaman dan pengetahuan yang otentik. Hal ini tercermin melalui berbagai variasi komentar individu.

Berdasarkan pemaparan di atas, terlihat bahwa masalah yang muncul adalah adanya pemberitaan mengenai Covid-19 di sejumlah media, sehingga mendorong pembentukan pengalaman yang berbeda-beda dari khalayak yang mengkonsumsi isi pemberitaannya. Oleh karena itu, tujuan dalam studi ini adalah mendeskripsikan pengalaman individu dalam melakukan proses kognitif terhadap informasi yang berkaitan dengan Covid-19 serta bagaimana individu memaknai realitas dalam situasi pandemi saat ini.

Penelitian sebelumnya yang disusun oleh Yoma Bagus Pamungkas (2017) berjudul "Proses Informasi Pada Peringatan Kesehatan Dalam Kemasan Rokok" mengungkap pemrosesan informasi yang dilakukan oleh para individu perokok ketika melihat gambar pada kemasan rokok. Nikolaus Ageng Prathama (2019) menyusun riset yang berjudul "Aktivitas Pemrosesan Informasi SARA Dari M edia Sosial" yang mengungkap pengalaman individu dalam berinteraksi dengan sejumlah informasi SARA dan memaknai fenomena hoaks SARA. Penelitianpenelitian sebelumnya tersebut menggunakan pendekatan teoritik yang sama 
dengan penelitian ini, yaitu konsep pemrosesan informasi. Namun demikian, pada penelitian ini kasus yang dikaji adalah berita atau informasi mengenai Covid-19 yang sedang berlangsung saat ini. Selain itu, penelitian ini juga menggunakan Uses and Gratification Theory untuk menjelaskan perilaku individu menggunakan media dalam situasi pandemi.

\section{Tujuan Penelitian}

Penelitian ini bertujuan mendeskripsikan pengalaman aktor sosial dalam melakukan proses kognitif terhadap informasi yang berkaitan dengan Covid-19 serta mendeskripsikan makna fenomena Covid-19 dalam situasi pandemi secara subyektif

\section{Kerangka Teori}

Dua tradisi pemikiran teoritik komunikasi yaitu tradisi sibernetika dan fenomenologi, digunakan dalam proses penelitian ini. Tradisi sibernetika digunakan untuk melihat aktivitas pemrosesan informasi yang dilakukan oleh individu ketika berinteraksi dengan informasi tentang Covid-19. Sedangkan tradisi fenomenologi mendeskripsikan hasil dari pemrosesan informasi dalam sistem kognitif individu, yang berwujud pengetahuan dan terbingkai secara subyektif dalam pengalaman individu.

\subsection{Tradisi Sibernetika}

Istilah sibernetika atau cybernetics, merupakan konsep yang diciptakan oleh Norbert Wiener untuk mendeskripsikan tentang kecerdasan buatan dan adanya feedback, sehingga membuat pemrosesan informasi dapat terjadi dalam kepala dan Iaptop manusia (Griffin, 2012 : 39). Gagasan komunikasi sebagai pemrosesan informasi muncul dari Claude Shannon, seorang ilmuwan riset yang mengembangkan konsep a mathematical theory of signal transmission (Griffin, 2000 : 36). Model distribusi pesan dari source kepada receiver yang dijelaskan Shannon, merupakan dasar dari 
asumsi gagasan pemikiran sibernetika sebagai pemrosesan informasi. Bagi Shannon, komunikasi merupakan ilmu yang dapat digunakan untuk menjaga keseimbangan antara predictability dan uncertainty secara optimal (Griffin, 2000 : 37). Terdapat lima tahap dalam pemrosesan informasi, yaitu (Engel, $1995: 5$ ) :
a) Pemaparan (Exposure)
b) Perhatian
c) Pemahaman
d) Penerimaan
e) Retensi

Jenis informasi yang dapat diakses oleh individu dari media massa dapat berupa teks, visual gambar, audio, dan video (audio visual). Hal ini berkaitan dengan sifat fisiologis otak manusia. Hemisfer kanan atau otak kanan memproses informasi bergambar atau visual. Sedangkan hemisfer kiri memproses informasi verbal atau semantik (Engel, 1995 : 34).

Sibernetika merupakan merupakan bagian dari teori sistem dan peta positivistik. Namun demikian, dalam perkembangannya, muncul secondorder cybernetics dari kelompok ahli yang menolak gagasan pemikiran (positivistik) sebelumnya. Kelompok ini dipimpin oleh Heinz von Foerster, yang kemudian dikenal mengembangkan gagasan alternatif.

Kelompok ini berpendapat bahwa peneliti tidak akan pernah dapat mengamati cara kerja sistem dari luar lingkungan sistem. Peneliti akan selalu terhubung sistem yang sedang diamati. Dengan kata lain, setiap individu yang mengamati sistem, secara langsung akan mempengaruhi dan dipengaruhi oleh sistem tersebut. Gagasan dari kelompok ini disebut dengan cybernetics of knowing (Littlejohn, $2008: 41$ ).

Penelitian ini menggunakan gagasan cybernetics of knowing, yang berusaha memahami berbagai sistem kehidupan manusia dalam berinteraksi dengan informasi tentang Covid-19. 


\subsection{Tradisi Fenomenologi}

Tradisi berikutnya adalah fenomenologi. Fenomenologi merupakan ilmu yang berfokus pada pengalaman sadar manusia ; usaha memahami proses mengetahui-process of knowing-melalui pengalaman langsung (Littlejohn, 2005 : 38). Secara konseptual, studi fenomenologi merupakan studi mengenai berbagai cara sadar manusia untuk mencapai pemahaman tentang obyek atau kejadian yang dialami manusia. Sebuah fenomena atau phenomenon merupakan penampakan suatu peristiwa, kejadian, obyek, atau kondisi dalam persepsi individu (Rahardjo, 2005 : 44). Bukti-bukti pada penelitian fenomenologi diperoleh dari laporan orang pertama tentang pengalaman hidupnya secara langsung (M oustakas, 1994 : 84).

Gagasan teoritik yang terdapat dalam fenomenologi, digunakan untuk mendeskripsikan hasil dari pemrosesan informasi yang terjadi di dalam sistem kognitif individu, yang berwujud struktur pengetahuan atau kognitif. Struktur ini berasal dari pengalaman sadar perceiver atau individu yang melakukan proses kognitif terhadap informasi Covid-19, sehingga dapat memaknai kehadiran fenomena Covid-19. Asumsi dalam fenomenologi yaitu orang akan menginterpretasikan pengalaman serta berusaha memahami dunia melalui pengalaman personal mereka secara sadar dan aktif. Proses interpretasi merupakan pusat dari gagasan fenomenologi, yang berasal dari Bahasa Jerman yaitu verstehen atau understandingproses untuk memberikan makna pada suatu pengalaman (Littlejohn, 2005 : 38-39). Terdapat tiga prinsip dasar fenomenologi yaitu (Littlejohn, 2005 : 38):

a) Pengetahuan adalah sesuatu yang disadari-pengetahuan tidak disimpulkan dari pengalaman individu, namun ditemukan dalam pengalaman sadar secara langsung. 
b) Makna dari sesuatu, mengandung aspek yang potensial pada hidup individu-dengan kata lain, cara individu menjalin relasi dengan obyek tertentu, akan menentukan maknanya secara individual.

c) Bahasa adalah vehicle untuk makna-individu mempunyai pengalaman mengenai dunia dari bahasa. Bahasa digunakan dalam proses mendefinisikan serta mengekspresikan dunia.

\subsection{Elaboration-Likelihood Theory}

Elaboration-Likelihood Theory (ELT) merupakan teori yang dikembangkan Richard Petty dan John Cacioppo. Keduanya adalah peneliti psikologi sosial. ELT termasuk dalam bagian teori persuasi-yang berusaha memprediksi cara dan momentum individu akan terbujuk atau tidak terbujuk pesan. Individu memiliki beragam cara untuk mengevaluasi informasi yang diterimanya-dengan pemikiran kritis yang rumit atau lebih sederhana dan kurang kritis. Inilah inti dari gagasan ELT (Littlejohn, 2008 :

74). Banyaknya integrasi di antara informasi baru dan pengetahuan yang sudah disimpan dalam ingatan disebut dengan elaborasi (Engel, 1995 : 21). Rute sentral dan rute perifer adalah rute pemikiran untuk memproses informasi. Elaboration, atau cara berpikir kritis, terjadi di dalam central route (rute sentral). Sedangkan pemikiran yang kurang kritis terjadi dalam peripheral (perifer) route.

Rute sentral bekerja secara aktif untuk memikirkan informasi dan mempertimbangkannya dengan keberadaan informasi lain yang telah tersimpan sebelumnya. Rute sentral berperan secara rasional. Otak manusia akan mencermati dan menguji informasi serta argumen yang diterima secara teliti. Elaborasi pesan atau informasi yang diterima oleh individu terjadi dalam rute sentral. Proses ini berlangsung lebih panjang dan akan bersifat permanen, sehingga akan diikuti dengan perubahan tindakan atau tingkah laku. 
Sementara itu, proses menerima atau menolak informasi yang diterima oleh individu secara lebih sederhana dan mudah, terjadi dalam rute periferal. Implikasinya, individu menjadi kurang kritis. Oleh karena itu, perubahan sikap hanya bersifat sementara. Sarwono (2002 : 232) menjelaskan bahwa sikap merupakan suatu reaksi evaluatif-yang menyenangkan atau tidak menyenangkan-terhadap sesuatu atau seseorang. Reaksi ini ditunjukkan dalam keyakinan, perasaan, atau perilaku tertentu yang diharapkan oleh seseorang. Namun demikian, elaboration likelihood merupakan variabel. Oleh karena itu, terdapat kemungkinan bahwa individu akan menggunakan kedua rute tersebut hingga batas tertentu, tergantung dengan tingkat relevansi personal yang ada dalam suatu isu bagi dirinya.

Dua faktor umum yang berkaitan dengan jumlah pemikiran kritis pada suatu argumen adalah motivasi dan kemampuan individu. Individu yang sangat termotivasi, cenderung akan menggunakan rute sentral. Sebaliknya, individu yang termotivasi rendah, kemungkinannya akan menggunakan rute perifer (Littlejohn, 2008 : 75). Oleh karena itu, Elaboration-Likelihood Theory digunakan untuk menjelaskan usaha komunikator dalam melakukan proses kognitif terhadap berbagai informasi mengenai fenomena Covid-19, yang berperan dalam pembentukan sikapnya.

\subsection{Uses and Gratifications Theory}

Uses and Gratifications Theory lebih berfokus pada konsumen atau audiens daripada pesan media. Pendekatan ini membayangkan bahwa audiens merupakan pengguna media yang diskriminatif. Individu menggunakan konten media secara aktif. Dengan kata lain, audien atau khalayak menggunakan pesan media untuk mencapai tujuan tertentu (Littlejohn, 2017 : 174). 
Uses and Gratifications Theory mempunyai lima asumsi. Pertama, audiens secara aktif menyeleksi berbagai media. Audiens memiliki beberapa pilihan di media ; audiens memilih apa yang ingin dilihat, dengar, atau saksikan (selective exposure). Kedua, khalayak itu aktif dan terarahkan pada tujuan. Anggota khalayak sebagian besar bertanggung jawab untuk memilih media demi memenuhi kebutuhan. Dengan kata lain, media hanya dianggap sebagai salah satu faktor yang memberikan kontribusi dalam pemenuhan kebutuhan. Ketiga, persaingan dari berbagai media untuk memperoleh perhatian khalayak. Institusi media mengetahui bahwa terdapat banyak pilihan untuk konsumsi media, sehingga institusi media membuat konten media yang akan diminati khalayak. Keempat, elemen sosial dan kontekstual membentuk aktivitas khalayak. Khalayak hidup dalam sebuah dunia dimana orang-orang dan realitas yang terjadi di sekitar khalayak mempengaruhi pola konsumsi media. Terakhir, efek dan penggunaan media oleh khalayak saling berhubungan. Pengaruh media hanya menyasar pada khalayak tertentu, karena individu-individu tersebut memilih untuk mengkonsumsi media.

Terdapat identifikasi hubungan antara jenis kepuasan atau penghargaan yang diterima individu dari media. Empat jenis kepuasaan yang bersifat umum : (1) Hiburan ; (2) Informasi ; (3) Identitas Personal ; serta (4) Interaksi dan Integrasi Sosial (seperti seseorang mampu berbicara mengenai program televisi dengan orang lain dalam jaringan sosial). Penelitian yang lain menguji berbagai jenis gratifikasi untuk berbagai media. Sebagai contoh, Li-Li, Yea-Wen Chen, dan Masato Nakazawa telah mengidentifikasi kepuasan. Para peneliti tersebut menyelesaikan analisis isi posting di forum diskusi online populer dan menemukan lima kepuasan utama diantara anggota khalayak : (1) Informasi Umum ; (2) Integrasi Sosial ; (3) Interaksi Parasosial (seperti seseorang bicara tentang dan bagaimana karakter di pertunjukan televisi) ; (4) Konflik Diantara Protagonis (seperti 
menikmati konflik diantara para karakter); dan (5) Penilaian Protagonis (seperti menghargai kebajikan dan sifat buruk karakter). Studi ini menganalisa penghargaan konsumen media yang dipertunjukkan dalam diskusi online tentang sebuah pertunjukan televisi (Littlejohn, 2017 : 175).

\section{Metode Penelitian}

Tipe penelitian ini adalah deskriptif kualitatif, yang menggunakan pendekatan fenomenologi. Oleh karena itu, instrumen penelitian yang digunakan yaitu indepth interview untuk memperoleh data primer yang berwujud pengalaman sadar dari 4 orang informan penelitian. Informan penelitian memiliki kualifikasi khusus yaitu berdomisili di Kota Semarang (zona merah penyebaran Covid-19) dan memperhatikan perkembangan berita atau informasi mengenai kasus Covid19 melalui sejumlah saluran informasi.

Terlebih dahulu dilakukan observasi non partisipan dan trial wawancara pada individu. Langkah berikutnya, setelah menemukan informan dan melakukan indepth interview, menyusun thematic portrayal, yang dimaksudkan untuk mengungkap pengalaman setiap informan yang beragam kedalam tema-tema pokok penelitian, sehingga makna inti dapat diungkap.

Penyusunan deskripsi tekstural dan struktural adalah langkah berikutnya dari tahap penelitian. Deskripsi tekstural disusun dari gambaran pengalaman seluruh informan. Sementara itu, gambaran pengalaman unik serta segala hal yang berhubungan dengan pengalaman tersebut disebut dengan deskripsi struktural.

Tindakan berpikir sadar, penilaian, imajinasi, dan mengumpulkan segala hal yang berhubungan dengan pengalaman diperlukan dalam penyusunan deskripsi struktural. Tujuan dari segala tindakan itu adalah mencapai inti makna struktural pengalaman, sehingga "the how" dapat digambarkan dan "the what" dari suatu pengalaman dapat dijelaskan (M oustakas, 1994 : 135). 
Sintesis makna dan struktural merupakan tahap berikutnya dalam penelitian fenomenologi. Sintesis dilakukan dengan menggabungkan deskripsi tekstural dan struktural secara intuitif kedalam suatu kesatuan atau rangkaian pernyataan tentang esensi pengalaman pada suatu fenomena secara menyeluruh (M oustakas, 1994 : 100).

\section{Hasil Penelitian dan Pembahasan}

\subsection{Aktivitas Pemilihan Informasi Teraktual dan Penggunaan Media}

Dalam kehidupan sehari-hari, para informan mengakses berbagai informasi seperti berita teraktual (politik, ekonomi, sosial, olahraga, keuangan), hiburan (gosip artis, berita olahraga, komedi, talkshow), informasi yang berkaitan dengan pekerjaan (bisnis), kesehatan (manfaat jamu tradisional), keagamaan, relasi sosial, informasi diskon atau promosi barang kebutuhan dari pusat perbelanjaan, dan informasi yang cenderung spesifik seperti informasi yang berkaitan dengan bidang akademik atau ilmiah. Secara dominan, informasi-informasi tersebut diperoleh melalui media internet.

Berbagai situs yang diakses untuk memperoleh informasi antara lain email (gmail), portal berita online (detik.com, kompas.com, tempo.co), cyber learning, situs resmi pemerintah pusat dan daerah, serta Facebook, Twitter, Instagram, Blog, Linkedln, aplikasi Line, What's app, dan Telegram. Hampir setiap hari, mereka terhubung dengan jaringan internet aktif selama minimum tiga jam melalui handphone atau komputer (laptop). Bahkan seorang informan selalu mengaktifkan jaringan internetnya selama 24 jam per hari, karena menggunakan fasilitas home-net. Namun demikian, mereka juga masih mengakses informasi tambahan melalui televisi, radio, media luar ruang (billboard atau baliho), dan media cetak (koran dan majalah) yang berada di sekitar mereka seperti di tempat bekerja, tempat tinggal, atau di sepanjang perjalanan. Bahkan media mouth (WOM) juga digunakan informan, ketika mereka berbagi informasi dengan 
keluarga, sahabat, tetangga, atau rekan kerja melalui kegiatan face-to-face interaction.

Fenomena tersebut memperlihatkan bahwa dalam menjalani aktivitas bekerja (bisnis) dan aktivitas lainnya sehari-hari, para individu terterpa informasi dengan intensitas yang cukup tinggi, sehingga mempengaruhi skema kognisi mereka yang telah terbentuk sebelumnya. Kognisi, yang didefinisikan oleh Sarwono (1999 : 76), adalah bagian dari jiwa manusia yang melakukan olah informasi-pengetahuan, pengalaman, dorongan, perasaan, dan lain-lain-baik yang datang dari luar maupun dari dalam diri manusia, sehingga terbentuk simpulan-simpulan yang dapat memandu perilaku. Keaktifan mereka mencari dan mengakses informasi, mendorong terjadinya pemrosesan informasi dalam sistem kognisinya secara berkelanjutan. Para individu mengakses berbagai informasi yang bervariasi, seperti informasi yang bersifat aktual-domestik yaitu informasi yang berkaitan dengan pekerjaan, akademik atau ilmiah, kesehatan, keuangan, keagamaan, relasi sosial, serta informasi yang berkaitan dengan diskon atau promosi barang kebutuhan rumah tangga. Bahkan informasi yang tidak berkaitan langsung dengan rutinitas sehari-hari seperti politik, ekonomi, sosial, hiburan, dan olahraga, juga menjadi bagian dari informasi yang dicari dan dipilih untuk kepentingan pribadi individual atau dibagikan kepada orang lain. Fenomena tersebut menunjukkan bahwa mereka melakukan selective exposure demi memenuhi needs dan want informasi, yang berkaitan dengan jenis dan jumlah aktivitasnya sehari-hari seperti bekerja, berbisnis, serta melakukan aktivitas-aktivitas lainnya. Dengan realitas seperti ini, mereka memiliki kemampuan untuk melakukan seleksi terhadap (terpaan) informasi yang akan dipilih atau diakses, termasuk terhadap jenis media yang dipilih. Secara dominan, mereka memilih media internet sebagai media gratifications untuk aktivitas utama dan aktivitas lainnya sehari-hari.

Dalam pemikiran Uses and Gratifications Theory, individu dianggap aktif, karena mampu untuk meneliti dan mengevaluasi beragam jenis media demi 
mencapai tujuan komunikasi (West dan Turner, 2008 : 101). Namun demikian, dalam konteks kasus ini, penentuan jenis media hanya sebagai akibat dari seleksi jenis informasi. Para individu cenderung melakukan seleksi "prioritas" pada jenis pesan atau informasi yang berkaitan secara langsung dengan aktivitas utama mereka sehari-hari, sehingga mendorong mereka untuk memilih media internet sebagai sumber dan saluran informasi yang diutamakan. Secara umum, informasi yang tersedia di dalam media internet lebih bersifat universal-archived, sehingga dapat diakses sewaktu-waktu oleh para penggunanya. M edia internet dipahami sebagai "infrastruktur penting" yang menopang kelancaran aktivitas utama mereka sehari-hari, seperti layanan email (surat elektronik) yang dapat digunakan untuk bekerja atau kepentingan studi.

Selain itu, mereka juga terhubung secara aktif dengan situs media sosial seperti Instagram, Facebook, Twitter, Blog, LinkedIn, aplikasi Line, Telegram, atau What'sapp untuk memperoleh informasi teraktual lainnya. Dalam catatan Rulli Nasrullah dijelaskan bahwa keunikan media sosial yaitu membentuk masyarakat berjejaring (network society), sehingga distribusi informasi dapat berlangsung terus-menerus (Nasrullah, 2015 : 103). Pada umumnya, mereka menggunakan media sosial untuk melakukan lima kegiatan yaitu pencarian informasi, pembagian informasi, berinteraksi dengan teman dan kerabat, menyimpan arsip pribadi (foto atau video), serta untuk kepentingan pekerjaan.

Para individu juga menggunakan televisi (KompasTV, MetroTV, NetTV, TVOne), radio, media cetak (surat kabar dan majalah), serta media luar ruang (billboard dan baliho) sebagai sumber informasi sehari-hari, namun keberadaan media-media tersebut cenderung hanya diposisikan sebagai sumber informasi pelengkap untuk hiburan atau penambah pengetahuan. Jenis informasi hiburan yang dipilih seperti berita olahraga, tayangan komedi, talkshow, atau gosip artis serta informasi mengenai berita teraktual dan lain-lainnya yang disajikan media. Faktor penting yang memberikan kontribusi secara langsung dalam aktivitas individu mengakses informasi dari internet adalah tersedianya perangkat 
teknologi seperti handphone dan komputer (laptop), yang lebih bersifat private serta dapat menghubungkan individu dengan koneksi atau jaringan aktif internet. Oleh karena itu, mobilitas mereka dalam beraktivitas secara personal maupun sosial dengan orang lain, cenderung tidak mengalami hambatan.

Pada studi yang dilakukan oleh Wilbur Schramm mengenai perilaku khalayak dalam memilih media tertentu, dijelaskan bahwa individu cenderung menerapkan prinsip kemudahan dan prinsip harap imbalan dalam menentukan jenis media yang dipilihnya (Rivers, 2003 : 311). Meskipun media-media seperti televisi, radio, media cetak (surat kabar dan majalah), atau media luar ruang (billboard dan baliho) juga tersedia dan relatif mudah diperoleh para informan, namun penggunaannya tidak terlalu menonjol. Para informan cenderung lebih memilih jenis media yang dapat menyediakan jenis informasi yang dibutuhkan serta berkaitan dengan aktivitas sehari-hari secara langsung, yaitu internet.

\subsection{Pemrosesan Informasi Covid-19}

Upaya pemrosesan berbagai informasi tentang Covid-19 yang berasal dari sejumlah saluran informasi dan komunikasi ke dalam sistem kognisi individu, dapat diperhatikan dari gambaran pengalaman seluruh informan penelitian yaitu dari : (1) Proses Kognitif Informasi Covid-19 ; serta (2) Struktur Kognitif Mengenai Fenomena Covid-19

\section{1) Proses Kognitif Informasi Covid-19}

Menurut pengamatan para informan, informasi tentang Covid-19 relatif mudah ditemukan melalui televisi, radio, portal berita online (tempo.co, kompas.com, detik.com), Facebook, Twitter, Instagram, dan aplikasi What's apps (grup) yang terhubung dengan jaringan internet. Oleh karena itu, dalam beraktivitas sehari-hari mengakses sejumlah informasi teraktual, mereka memiliki peluang untuk menerima terpaan informasi Covid-19 sewaktuwaktu. Terpaan merupakan suatu tindakan menerima komunikasi, baik secara pasif atau aktif dari sumbernya (Berelson and Steiner, 1964 : 14). 
Namun demikian, informasi Covid-19 juga ditransmisikan melalui word of mouth (WOM).

Informasi tentang Covid-19 merupakan informasi yang berkaitan atau berkonten mengenai perkembangan penyebaran virus Covid-19, terutama yang terjadi di Indonesia. Sejumlah informasi yang diperoleh dan diingat oleh informan yaitu awal munculnya virus Covid-19 di Wuhan Tiongkok, akibat yang diterima oleh pasien Covid-19, jumlah penderita Covid-19, awal masuknya Covid-19 di Indonesia (kasus di Depok Jawa Barat), penyebaran Covid-19 ke sejumlah daerah, jumlah korban meninggal, jumlah pasien yang dinyatakan sembuh, penanganan Covid-19 oleh pemerintah, dan kebijakan pemerintah yang berkaitan dengan penyebaran Covid-19. Kemunculan informasi-informasi tersebut, cenderung mendorong involuntary attention mereka secara individual. Dalam perspektif komunikasi pemasaran, involuntary attention (perhatian yang tidak disengaja) terjadi ketika para konsumen (individu) diekspos pada sesuatu yang mengejutkan, baru, mengancam, atau tidak terduga dan mereka menanggapinya secara otonomis dengan mengarahkan serta mengalokasikan perhatian pada rangsangan yang ada (Mowen, 2002 : 99).

Pada awalnya, para individu dihadapkan pada situasi unaware, karena informasi-informasi yang muncul tersebut tidak menjadi bagian dari informasi yang dipilih untuk aktivitas sehari-hari (informational goal) mereka. Kemunculan informasi-informasi berkonten Covid-19 merupakan dampak lain, yang merupakan secondary effect dalam aktivitas mereka memilih serta mengakses informasi sehari-hari. Oleh karena itu, mereka melakukan information grouping untuk informasi yang bersifat aktual-domestik, informasi tambahan pengetahuan, dan informasi yang berkaitan dengan Covid-19.

Para ahli psikolog kognitif menyatakan bahwa setiap hari individu terekspos dengan berbagai informasi dalam jumlah yang sangat besar. 
Namun informasi-informasi tersebut disaring, sehingga hanya sebagian kecil informasi yang dapat mencapai pikiran sadar dan menarik perhatian individu untuk diproses serta disimpan dalam memori jangka panjang (Baran dan Davis, 2010 : 311). Proses ini terjadi di dalam sistem kognitif individu. Kognitif atau kognisi merupakan bagian dari jiwa manusia yang melakukan olah informasi-pengetahuan, pengalaman, dorongan, perasaan, dan lain-lainbaik yang datang dari luar maupun dari dalam diri manusia, sehingga terbentuk simpulan-simpulan yang dapat memandu perilaku (Sarwono, 1999 : 76). Sebagian dari informasi Covid-19 yang diperoleh dan diingat oleh para informan, dapat menarik attention dan memotivasi (motivation) mereka untuk mengikuti perkembangannya. Pada tahap ini, terjadi pemrosesan sejumlah informasi tentang Covid-19 dalam sistem kognitif individu.

John C. Mowen dan Michael Minor menjelaskan bahwa pemrosesan informasi merupakan proses di mana para individu diarahkan untuk menuju informasi, diajak untuk melakukan pencarian informasi, memahami informasi, menempatkan informasi di dalam memori mereka, dan membukanya kembali untuk digunakan kemudian (Mowen, 2002 : 78). Pada saat individu terpapar berita atau informasi Covid-19 yang menarik perhatiannya (attention), mereka termotivasi (motivation) untuk mengikuti perkembangan informasi tersebut melalui berbagai saluran informasi dan komunikasinya. Motivasi merupakan suatu kecenderungan (sifat yang merupakan pokok pertentangan) dalam diri individu yang membangkitkan topangan dan tindakan (Setiadi, 2003 : 25). Dalam konteks ini, motivasi individu berwujud keinginan untuk mengikuti perkembangan dari suatu informasi Covid-19 yang diperolehnya.

Dalam gagasan Elaboration Likelihood Theory (ELT) yang dikembangkan oleh Richard Petty dan John Cacioppo, dijelaskan bahwa individu (komunikator) akan berusaha memproses pesan-pesan persuasif dengan caranya (Littlejohn, 2017 : 59). Informasi yang diikuti 
perkembangannya antara lain informasi tentang Covid-19 secara global, penyebaran Covid-19 di Indonesia, jumlah pasien sembuh, jumlah korban meninggal, dan kebijakan pemerintah tentang Pembatasan Kegiatan Masyarakat (PKM). Kelima informasi ini mendorong rasa penasaran dan menyebabkan cognitive dissonance pada individu.

\section{2) Struktur Kognitif Mengenai Fenomena Covid-19}

Dari aktivitas mengkonsumsi berbagai informasi berkonten Covid-19 yang tidak disengaja maupun yang disengaja, di dalam sistem kognitif individu terbangun sebuah struktur pengetahuan (kognitif) mengenai fenomena Covid-19. Dalam catatan Sarlito Wirawan Sarwono dijelaskan bahwa struktur kognitif merupakan serangkaian sifat yang terorganisasi dan digunakan oleh individu untuk mengidentifikasi serta mendiskriminasi suatu obyek atau peristiwa tertentu (Sarwono, 2013 : 85). Struktur ini berasal dari pemahaman individual mereka secara menyeluruh mengenai sejumlah informasi tentang Covid-19 yang telah diprosesnya. Pemahaman mengacu pada bagaimana individu mengorganisasikan dan menginterpretasikan informasi (Mowen, 2002 : 115).

Proses pembentukan pemahaman individu terjadi dalam aktivitas komunikasi mereka sehari-hari melalui perubahan skema kognitif (cognitive) dan sikap atau suasana emosional (affective) individu secara bervariasi. Skema kognitif, yang diartikan sebagai naskah dalam pikiran individu mengenai alur suatu peristiwa (Ardianto, 2009 : 56), cenderung menjadi berubah ketika individu memberikan perhatian (attention) pada sejumlah informasi baru yang mendekati mereka, yang kemudian diproses, sehingga terjadi penambahan input dalam sistem kognisi individualnya, yang terungkap melalui berbagai penilaian, pendapat, ataupun ungkapan, dan ekspresi emosional serta perilaku komunikasi tertentu mereka ketika berinteraksi dengan informasi virus corona yang dianggap tidak sesuai 
harapannya. Sikap merupakan perasaan umum-baik negatif maupun positif, yang berkelanjutan terhadap-seseorang, obyek, dan suatu masalah (Shimp, 2000 : 225). Dalam konteks ini, sikap mencakup ungkapan atau ekspresi emosional individu seperti kekecewaan, kemarahan, cenderung tenang, dan perilaku-perilaku komunikasi tertentu ketika mereka berinteraksi dengan informasi yang berkaitan dengan Covid-19.

Terdapat empat pemaknaan mengenai Covid-19 yang dipahami oleh para informan. Pertama, Covid-19 merupakan virus mematikan yang berasal dari hewan tertentu. Faktor keserakahan manusia yang ingin mengkonsumsi binatang, yang seharusnya tidak layak untuk dimakan menjadi penyebab utama kemunculan virus ini dalam kehidupan manusia. Kedua, Covid-19 merupakan bagian dari hasil ujicoba yang dilakukan oleh sejumlah ilmuwan dunia untuk percobaan laboratorium yang gagal, namun malah menyebar kepada manusia lainnya.

Ketiga, Covid-19 menjadi bagian dari teknik rekayasa genetika dan mikrobiologi dari sejumlah ilmuwan terkemuka di dunia yang terafiliasi dengan lembaga farmasi global, yang berkepentingan untuk menciptakan virus dan vaksin antivirus untuk dijual ke seluruh dunia. Keempat, fenomena Covid-19 hanya rekayasa dari para politisi Negara besar seperti Amerika Serikat, Tiongkok, Eropa, dan lain-lain untuk menciptakan kepatuhan dan dominasi mereka terhadap Negara-negara yang lebih kecil. Kelima, Covid-19 merupakan bagian dari hasil seleksi alam untuk mengurangi populasi manusia di dunia yang semakin mengurangi jumlah hutan untuk habitat virus-virus atau bakteri yang seharusnya berada untuk mengontrol populasi binatang.

Terkait dengan pemberitaan media tentang Covid-19, terdapat dua pendapat yang menonjol. Pendapat pertama dikemukakan oleh tiga orang informan yang bersepakat bahwa media terutama televisi cenderung memberitakan kasus Covid-19 secara berlebihan, karena hanya 
memperbanyak pemberitaan tentang kasus pasien yang meninggal, pasien yang ditolak, atau kasus kontroversial lainnya yang berkaitan dengan kematian pasien covid-19. Bahkan seorang informan menyebut bahwa TvOne menciptakan kecemasan bagi khalayak, karena menampilkan reporter yang mengenakan atribut masker gas dan liputan di daerah zona merah Covid-19, sehingga khalayak yang menyaksikan program berita tersebut menjadi takut akan keadaan yang ditimbulkan oleh Covid-19.

Fenomena tersebut menunjukkan adanya kombinasi konten visual dan verbal yang tidak seimbang. Khalayak diberi terlalu banyak gambar yang menyerang mental, namun konteks informasinya terlalu sedikit. Terkadang gambar yang digunakan tidak relevan dengan kisahnya- membingungkan dan tidak memberikan informasi (Baran dan Davis, 2010 : 316). Secara tidak langsung, media televisi tidak menjalankan fungsinya dengan baik. M enurut Effendy, fungsi media dalam komunikasi massa yaitu fungsi informasi, pendidikan, dan memengaruhi (Ardianto, 2009 : 14). Namun demikian, dalam konteks pemberitaan yang berkaitan dengan pandemi Covid-19, media televisi cenderung menyebarkan informasi yang tidak utuh kepada pemirsa, sehingga tidak konsisten dengan fungsi dasar normatifnya.

Dua orang informan mengaku merasakan kecemasan yang cukup tinggi dengan adanya pandemi Covid-19 ini, sehingga mendorong keduanya untuk lebih berhati-hati. Sehari-hari mereka mengenakan masker, membawa handsanitizer, dan mengurangi aktivitas kolektif seperti berbelanja ke pasar atau rapat dalam satu ruangan dengan sejumlah orang.

Pendapat kedua dikemukakan oleh seorang informan yang menilai bahwa pemberitaan media, termasuk televisi, telah menyajikan keberagaman kasus. Dari sosialisasi untuk pencegahan menyebarnya Covid-19, jumlah daerah yang rawan, jumlah pasien yang sembuh, jumlah pasien meninggal, kebijakan pemerintah, hingga dampak dari pandemi Covid-19 dalam berbagai aspek telah diberitakan oleh media. 
Persoalan Covid-19 yang telah meluas, juga menjadi perhatian pemerintah secara nasional, sehingga mendorong Presiden Joko Widodo membentuk Satuan Gugus Tugas Covid-19 yang secara khusus berupaya menanggulangi serta mencegah penyebaran virus corona atau Covid-19 secara lebih meluas. Para informan sepakat bahwa pemerintah telah berupaya merespon kasus Covid-19. Namun demikian, upaya pemerintah ini ditanggapi secara beragam oleh informan.

Seorang informan dengan kritis dan skeptis menilai bahwa pemerintah terkesan santai dalam mengatasi persoalan pandemi Covid-19. Menurutnya pemerintah tidak terlihat berusaha untuk menemukan atau mendorong para ilmuwan menciptakan vaksin yang dapat digunakan untuk mencegah penyebaran virus Covid-19 dalam jangka panjang seperti pada kasus wabah cacar air yang pernah terjadi beberapa tahun lalu. Selain itu, dalam pelaksanaan kebijakan Pembatasan Sosial Berskala Besar (PSBB), pemerintah terkesan tidak tegas dengan membuka sejumlah jalur perhubungan, terutama jalur udara, yang memungkinkan terjadinya mobilisasi penduduk, sehingga membuka peluang terjadinya penularan virus.

Pada konteks peran pemerintah daerah, dirinya juga menyoroti adanya ketidaktegasan dari pemerintah daerah (Kota Semarang dan Provinsi Jawa Tengah), yang tidak memberikan perhatian khusus pada sejumlah pasar tradisional, terutama pasar yang menjual binatang seperti Pasar Kobong (ikan dan unggas), sehingga masih terjadi aktivitas yang padat. Dampak dari adanya kepadatan pengunjung dari pasar tersebut adalah ditemukannya sejumlah pedagang yang terinfeksi positif Covid-19, sehingga meningkatkan jumlah pasien Covid-19 di Kota Semarang dan Provinsi Jawa Tengah.

Sementara tiga orang informan menilai bahwa pemerintah telah berupaya dengan baik, meskipun seharusnya pemerintah tidak menjadi aktor tunggal dalam menangani wabah Covid-19. Menurut mereka, peran aktif masyarakat terutama para tokoh masyarakat (agama, adat, lokal) sangat 
dibutuhkan untuk mendorong masyarakat lebih menyadari tentang bahaya serta mematikannya virus Covid-19, sehingga masyarakat dapat lebih disiplin untuk melaksanakan anjuran dari pemerintah.

Seorang informan juga memberikan penilaian mengenai adanya peran negatif dari seorang tokoh masyarakat yang berada di sekitar tempat tinggalnya. Tokoh tersebut memprovokasi warga yang lain untuk melakukan penolakan dan penghadangan terhadap rombongan pengantar jenasah seorang perawat Rumah Sakit Umum Pusat Kariadi Semarang yang meninggal karena terinfeksi Covid-19. Para demonstran menolak jenasah untuk dimakamkan di tempat pemakaman umum yang berada di wilayahnya.

\section{Simpulan}

Hasil dari penelitian ini memperlihatkan bahwa para individu selalu terhubung dengan sejumlah media massa seperti radio, koran, majalah, televisi, media luar ruang (baliho dan billboard), serta media internet untuk mengakses beragam informasi sehari-hari. Media internet cenderung menjadi media yang dominan dipilih dan digunakan, karena lebih bersifat universal-archive, sehingga informasinya dapat diakses sewaktu-waktu. Terkait dengan berita atau informasi tentang Covid-19, para informan memperolehnya dari berbagai saluran informasi yang digunakannya masing-masing. Mereka memberikan penilaian secara beragam mengenai fenomena Covid-19, berita Covid-19, dan upaya pemerintah dalam mengatasi pandemi Covid-19. Berdasarkan hasil penelitian ini, implikasi praktis ditujukan bagi para pengelola media terutama televisi agar dapat menyajikan informasi tentang Covid-19 yang tidak menciptakan kecemasan secara berkelanjutan bagi khalayak atau pemirsa.

\section{Daftar Pustaka}

Ardianto, Elvinaro, Lukiati Komala, dan Siti Karlinah. (2009). Komunikasi Massa : Suatu Pengantar. Bandung: Simbiosa Rekatama Media 
Baran, Stanley J. dan Dennis K. Davis. (2010). Teori Komunikasi Massa Dasar, Pergolakan, dan M asa Depan : Edisi Lima. Jakarta : Salemba Humanika

Berelson and G.A. Steiner. (1964). Human Behavior: An Inventory of Scientific Finding. New York: Harcourt, Brace, and World Inc

Devito, Joseph A. (2001). The Interpersonal Communication Book : Ninth Edition. New York: HarperCollins Publishers, Inc

Engel, James F., Roger D. Blackwell, dan Paul W. Miniard. (1995). Perilaku Konsumen: Edisi Keenam. Jakarta : Binarupa Aksara

Griffin, EM . (2000). A First Look At Communication Theory fourth edition. New York: McGraw-Hill

Griffin, EM. (2012). A First Look At Communication Theory eighth edition. New York: McGraw-Hill

Littlejohn, Stephen W. and Karen A. Foss. (2005). Theories of Human Communication eight edition. California : Wadsworth Publishing Company

Littlejohn, Stephen W. and Karen A. Foss. (2008). Theories of Human Communication ninth edition. California : Wadsworth Publishing Company

Littlejohn, Stephen W., Karen A. Foss, and John G. Oetzel. (2017). Theories of Human Communication : Eleventh Edition. Long Grove : Waveland Press Inc

Moustakas, Clark. (1994). Phenomenological Research Methods. London : SAGE Publications

Mowen, Jhon C. dan M ichael Minor. (2002). Perilaku Konsumen : Edisi Kelima. Jakarta: Erlangga

Nasrullah, Rulli. (2015). Media Sosial : Perspektif Komunikasi, Budaya, dan Sosioteknologi. Bandung : Simbiosa Rekatama Media

Rahardjo, Turnomo. (2005). M enghargai Perbedaan Kultural : M indfulness Dalam Komunikasi Antaretnis. Yogyakarta : Pustaka Pelajar

Rivers, William, L., Jay W. Jensen, dan Theodore Peterson. (2003). Media Massa dan Masyarakat M odern (Edisi Kedua). Jakarta : Prenada M edia

Sarwono, Sarlito Wirawan. (1999). Psikologi Sosial Individu dan Teori-Teori Psikologi Sosial. Jakarta : Balai Pustaka

Sarwono, Sarlito Wirawan. (2002). Psikologi Sosial : Individu dan Teori-Teori Psikologi Sosial. Jakarta : Balai Pustaka

Sarwono, Sarlito Wirawan. (2013). Teori-Teori Psikologi Sosial. Jakarta : RajaGrafindo Persada

Setiadi, Nugroho J. (2003). Perilaku Konsumen : Perspektif Kontemporer Pada Motif, Tujuan, dan Keinginan Konsumen. Jakarta : Kencana

Shimp, Terence A. (2000). Periklanan Promosi : Aspek Tambahan Komunikasi Pemasaran Terpadu Jilid Satu : Edisi Kelima. Jakarta : Erlangga

West, Richard dan Lynn H. Turner. (2008). Pengantar Teori Komunikasi Analisis Dan Aplikasi. Jakarta: Salemba 


\section{Sumber Internet}

CNN Indonesia. (2020). Korban Tewas Di Italia 7505 Orang. Diakses melalui https:// www.cnnindonesia.com/internasional/20200327070926-134-

487349/update-corona-global-korban-tewas-di-italia-7505-orang pada tanggal $28 \mathrm{M}$ aret 2020 pukul 19.00

Harsono, Fitri Haryanti. (2020). Panik Warga Soal Virus Corona, Bagaimana Pemerintah Menanganinya. Diakses melalui https:// www.liputan6.com/health/read/4168268/headline-panik-wargasoal-virus-corona-bagaimana-pemerintah-menanganinya pada tanggal 19 Maret 2020 pukul 21.00

Kompas. (2020). Kasus Per Provinsi. Diakses melalui https://www.kompas.com/covid-19 pada tanggal 3 M ei 2020 pukul 17.05

Maesaroh, Siti. (2020). Beritakan Virus Corona Yang Masuk Indonesia Sembari Pake Gas Mask Reporter Televisi Ini Kena Semprot Netizen. Diakses melalui https://www.grid.id/read/042047274/beritakan-virus-coronayang-masuk-indonesia-sembari-pake-gas-mask-reporter-stasiun-televisiini-kena-semprot-netizen-bahkan-dokter-di-afrika-gak-gitubanget?page=all pada tanggal 19 April 2020 pukul 20.00

Nielsen Indonesia. (2017). Penetrasi M edia Televisi Masih Yang Tertinggi. Diakses melalui https://databoks.katadata.co.id/datapublish/2017/07/27/penetrasitelevisi-masih-yang-tertinggi pada tanggal $7 \mathrm{M}$ aret 2020 pukul 18.08

Nursyabani, Fira. (2020). Ini Asal Muasal Nama Virus Corona. Diakses melalui https:// www.ayobandung.com/read/2020/03/24/83696/ini-asal-muasalnama-virus-corona pada tanggal 23 Maret 2020 pukul 19.00

Ramdani, Eko. (2020). Beragam Tanggapan Menyikapi Corona. Diakses melalui https://news.act.id/berita/beragam-tanggapan-menyikapi-corona pada tanggal 9 M ei 2020 pukul 22.00

Sucahyo, Nurhadi. (2020). Virus Corona Di Media, Edukatif Atau Bikin Panik. Diakses melalui https://www.voaindonesia.com/a/virus-corona-di-mediaedukatif-atau-bikin-panik-/5321258.html pada tanggal 23 Maret 2020 pukul 20.00

\section{Jurnal Dan Laporan Penelitian}

Pamungkas, Yoma Bagus. (2017). Proses Informasi Pada Peringatan Kesehatan Dalam Kemasan Rokok. Jurnal IImu Komunikasi. Universitas Diponegoro Semarang

Prathama, Nikolaus Ageng. (2019). Aktivitas Pemrosesan Informasi SARA Dari M edia Sosial. Tesis Ilmu Komunikasi. Universitas Diponegoro Semarang 